\title{
Effects of Evapotranspiration on Treatment Performance in Constructed Wetlands: Experimental Studies and Modeling
}

\author{
Donald A. Beebe ${ }^{\mathrm{a}, 1, *}$, James W. Castle ${ }^{\mathrm{a}}$, F.J. Molz ${ }^{\mathrm{a}}$, and John H. Rodgers Jr. ${ }^{\mathrm{b}}$ \\ ${ }^{a}$ Department of Environmental Engineering and Earth Sciences \\ Clemson University, \\ Clemson, SC 29634, USA \\ ${ }^{\mathrm{b}}$ School of Agricultural, Forest, and Environmental Sciences \\ Clemson University, \\ Clemson, SC 29634, USA \\ ${ }^{1}$ Present Address: Department of Earth Sciences \\ University of South Alabama, \\ Mobile, AL, 36688, USA \\ *Corresponding Author: \\ Donald A. Beebe \\ 5871 USA Drive N. \\ LSCB Room 136 \\ Mobile, AL, 36688-0002, USA \\ Phone: (251) 460 - 6381 \\ Fax: (251) 461 - 1487 \\ dbeebe@southalabam.edu
}




\section{$\underline{\text { Abstract }}$}

Evapotranspiration (ET) can affect treatment performance in constructed wetlands

42 by enhancing constituent transport through the hydrosoil where treatment reactions occur.

43 Additionally, ET can decrease volumetric flow thereby increasing hydraulic retention

44 time and increasing concentrations of dissolved constituents. This research aims to assess

45 the net effects of water loss attributed to ET on constructed wetland performance and

46 determine the significance of plant transpiration on vertical transport of constituents. A

47 flowing wetland lysimeter constructed using 265-L storage containers filled with sand

48 and Typha latifolia was used to record ET and determine crop coefficient during summer

49 2011. Results indicate that ET from the lysimeter was 2.5 times greater than calculated

50 reference $\operatorname{ET}\left(K_{c}=2.5 ; \mathrm{R}^{2}=0.96\right)$. The calculated crop coefficient was used in

51 conjunction with a first-order tank-in-series model to predict removal of a conservative

52 constituent $\left(k=0.2 \mathrm{~d}^{-1}\right)$ and readily treatable constituent $\left(k=1.2 \mathrm{~d}^{-1}\right)$ in a constructed

53 wetland $\left(20 \mathrm{~cm}\right.$ and $40 \mathrm{~cm}$ water depths, 4-day nominal HRT, and $100 \mathrm{mg} \mathrm{L}^{-1}$ constituent

54 loading) operating under a range of $\operatorname{ET}\left(0,10,20\right.$, and $\left.30 \mathrm{~mm} \mathrm{~d}^{-1}\right)$. The model predicts

55 that removal efficiency of the conservative constituent decreases with increasing ET,

56 while removal efficiency of the readily treatable constituent increases with increasing ET.

57 In addition, eight vertical tracer tests were performed on wetland cells with either

58 trimmed or untrimmed T. latifolia to measure transport time of tracer solution from the

59 water surface to a depth of $5 \mathrm{~cm}$. Mean tracer arrival time differed significantly $(\mathrm{p}=1.2 \mathrm{x}$

$6010^{-8}$ ) between the untrimmed and trimmed cells (104 minutes versus 450 minutes, 
61 respectively) demonstrating that plant transpiration contributes significantly to vertical

62 flow through hydrosoil.

63 Keywords: Constructed Wetlands, Evapotranspiration, Tracer Tests, Modeling, Typha

64 Latifolia, Cattails 
66 Water loss in constructed wetland treatment systems (CWTSs) occurs primarily

67 through the combined effects of open water evaporation and plant transpiration,

68 collectively termed evapotranspiration. Because CWTSs are typically constructed with a

69 lined bottom to prevent infiltration of contaminated water to underlying soil,

70 evapotranspiration is a key component of the water balance. Evapotranspiration is driven

71 primarily by the transformation of insolation energy to latent heat of vaporization of

72 liquid water.

73 Numerous studies have been performed to quantify evapotranspiration from

74 wetlands containing Typha latifolia (i.e. broadleaf cattails) with conflicting results

75 attributed to differing measurement methods and lysimeter designs (Allen and Prueger,

76 1992; Allen et al., 1997; Anderson and Idso, 1987; Idso and Anderson, 1988; Otis, 1914;

77 Idso, 1981; Snyder and Boyd, 1987; Towler et al., 2004). As explained by Idso and

78 Anderson (1988), evapotranspiration can be influenced by the "oasis effect" (Shaw,

79 1967) resulting in elevated evapotranspiration from isolated, small stands of vegetation

80 compared to large expanses of vegetation. Incoming latent heat from surrounding dry

81 fetch is advectively exchanged through the periphery of isolated stands of vegetation,

82 leading to an increase in incoming energy and corresponding increase in

83 evapotranspiration (Idso and Anderson, 1988; Towler et al., 2004). Evapotranspiration is

84 also dependent on regional meteorological factors including air temperature, relative

85 humidity, solar radiation, and wind speed, as well as CWTS design features including

86 plant species diversity and density (Allen et al., 1998). 
88 treatment performance by removing water from the system (thus increasing hydraulic

89 retention time) and increasing concentrations of dissolved constituents. Differences in

90 evapotranspiration attributed to CWTS size, climatic region, and plant selection can lead

91 to inaccurate predictions of treatment performance when using previously determined

92 removal rate coefficients. Because removal performance data collected from small, pilot-

93 scale CWTS studies may be applied to designing full-scale CWTSs in different climatic

94 regions, the extent to which differing evapotranspiration can affect treatment is of 95 interest.

Additionally, because both the inflow and outflow of free water surface (FWS)

97 CWTSs are located above the hydrosoil, a decreasing hydraulic head with depth is

98 needed to advectively transport targeted constituents to the hydrosoil where treatment by

99 specific redox-driven reactions occurs (Kadlec, 1999; Kadlec and Wallace, 2009; Martin

100 and Reddy, 1997; Martin et al., 2003). Previous studies suggest that plant transpiration

101 plays a role in establishing a vertical hydraulic gradient within wetland hydrosoil (Martin

102 et al., 2003). The extent to which constituents are transported advectively can be

103 estimated through a transpiration to evapotranspiration ratio based on the assumption that

104 water lost through plant transpiration must move through the root zone (Kadlec and

105 Wallace, 2009). However, root density and location can affect flow through the hydrosoil

106 and water column (Figure 1). Therefore, the ability of plant transpiration to vertically

107 transport constituents warrants investigation to determine if FWS CWTSs are capable of

108 supporting treatment by redox-driven reactions in the hydrosoil. 
The objectives of this paper are to (1) determine the crop coefficient for a small-

110 stand, pilot-scale CWTS, (2) predict differences in constructed wetland treatment

111 performance attributed to evapotranspiration-driven water-loss, and (3) measure the

112 effects of plant transpiration on vertical flow of constituents. Completion of these

113 objectives provides a fundamental understanding of the effects of evapotranspiration on

114 treatment performance in FWS CWTSs containing T. latifolia.

2. Materials and Methods

\subsection{Pilot-scale Crop Coefficients for Typha latifolia}

T. latifolia evapotranspiration $\left(E T_{c}\right)$ was monitored using four $0.5-\mathrm{m}^{2}$

119 with dimensions similar to pilot-scale CWTSs used in many previous studies (e.g

120 Dorman et al., 2009; Horner et al., 2012; Kanagy et al., 2008; Spacil et al., 2011). The

121 lysimeter consisted of four 265-L troughs, each filled to a depth of $45 \mathrm{~cm}$ with sandy

122 river sediment collected from nearby 18-mile Creek (Clemson, SC) and planted to field

123 density (approximately 20 plants per trough or 10 plants per $\mathrm{m}^{2}$ ) with $T$. latifolia

124 collected from nearby aquaculture ponds. The four troughs were connected in series with

125 2.5-cm diameter polyvinyl chloride (PVC) piping and arranged for gravity flow, with

126 fixed overflow pipes installed in each trough to maintain a constant head and water-depth

127 of $15 \mathrm{~cm}$ (Figure 2). Water was supplied to the first trough at a constant rate of $6 \mathrm{~L} \mathrm{~h}^{-1}$

$128\left(6 \times 10^{6} \mathrm{~mm}^{3} \mathrm{~h}^{-1}\right)$ by a Fluid Metering Inc. ${ }^{\circledR}$ pump (QG400). The lysimeter was allowed

129 to mature for approximately 3 years before any $E T_{c}$ data were collected. The plants were

130 fertilized periodically to promote vigorous growth. The lysimeter remained outdoors in 
131 Clemson, $\mathrm{SC}\left(34.69^{\circ} \mathrm{N}, 82.81^{\circ} \mathrm{W}\right)$ for the duration of the experiment from July through 132 August of 2011.

133 Volumetric outflow of the lysimeter was monitored using a RainWise® Inc.

134 tipping bucket rain gauge placed under the outflow pipe of the last trough of the lysimeter 135 (Figure 2). The rain gauge was connected to a RainWise® RainLog digital data logger 136 with $256 \mathrm{kB}$ of non-volatile memory capable of recording flow information at a 137 resolution of 1 minute. The rain gauge was calibrated prior to the experiment using ten 138 timed, one-minute intervals of a constant $6 \mathrm{~L} \mathrm{~h}^{-1}$ flow rate provided by the FMI QG400 139 pumps. Hourly volumetric outflow data were recorded and downloaded for three 5- to 7140 day intervals in July and August after the plants had reached maturity.

$141 E T_{c}\left(\mathrm{~mm} \mathrm{~h}^{-1}\right)$ was calculated as the difference between the volumetric inflow and 142 outflow divided by the surface area of the lysimeter for data collected during dry periods 143 with no precipitation (Eqn. 1).

$$
E T_{c}=\frac{Q_{\text {in }}-Q_{o u t}}{S A}
$$

145 Where $Q_{\text {in }}$ is volumetric inflow of the lysimeter $\left(6 \times 10^{6} \mathrm{~mm}^{3} \mathrm{~h}^{-1}\right), Q_{\text {out }}$, is measured 146 volumetric outflow of the lysimeter $\left(\mathrm{mm}^{3} \mathrm{~h}^{-1}\right)$, and $S A$ is measured surface area of the 147 lysimeter $\left(2 \times 10^{6} \mathrm{~mm}^{2}\right)$.

148 Small-stand crop coefficients for T. latifolia were determined using linear 149 regressions of hourly $E T_{c}$ measured from the lysimeter and hourly reference 150 evapotranspiration $\left(E T_{o}\right) . E T_{o}$ values were calculated using the FAO-56 Penman151 Monteith method (Allen et al., 1998; Penman 1963) from meteorological data collected 152 with an on-site Davis Instruments ${ }^{\circledR}$ Vantage Pro 2 weather station. The FAO-56 
153 Penman-Monteith method (Eqn. 2) was used to calculate $E T_{o}$ for a reference crop with an 154 assumed crop height of $0.12 \mathrm{~m}$, fixed surface resistance of $70 \mathrm{~s} \mathrm{~m}^{-1}$, and albedo of 0.23 .

155 This method was selected because it meets the precision required for calculating crop

156 coefficients using readily acquired meteorological data (e.g. temperature, dew point, wind 157 speed, and solar radiation) and is commonly used in other evapotranspiration studies (e.g. 158 Allen et al., 1998).

$$
E T_{o}=\frac{(0.408) \Delta\left(R_{n}\right)+\gamma \frac{37}{\mathrm{~T}+273} \mathrm{u}_{2}\left(\mathrm{e}_{\mathrm{s}}-\mathrm{e}_{\mathrm{a}}\right)}{\Delta+\gamma\left(1+0.34 \mathrm{u}_{2}\right)}
$$
where $E T_{o}$ is reference evapotranspiration $\left(\mathrm{mm} \mathrm{h}^{-1}\right)$ calculated from meteorological data; $161 \Delta$ is slope of the saturation vapor pressure temperature relationship $\left(\mathrm{kPa}^{\circ} \mathrm{C}^{-1}, 1 \mathrm{kPa}=\right.$ $1621 \times 10^{3}$ pascals); $R_{n}$ is measured net radiation $\left(\mathrm{MJ} \mathrm{m} \mathrm{m}^{-2} \mathrm{~h}^{-1}, 1 \mathrm{MJ}=1 \times 10^{6}\right.$ joules $) ; \gamma$ is 163 psychrometric constant $\left(\mathrm{kPa}^{\circ} \mathrm{C}^{-1}\right) ; T$ is measured air temperature $\left({ }^{\circ} \mathrm{C}\right) ; u_{2}$ is wind speed $164\left(\mathrm{~m} \mathrm{~s}^{-1}\right)$ measured at a height of $2 \mathrm{~m} ;\left(e_{s}-e_{a}\right)$ represents vapor pressure deficit of the air $165(\mathrm{kPa}) ; e_{s}$ is saturation vapor pressure of the air $(\mathrm{kPa}) ; e_{a}$ is vapor pressure of the air $(\mathrm{kPa})$. 166 Values for $\Delta, \gamma, e_{s}$, and $e_{a}$ were calculated from meteorological data collected with the on167 site weather station (Table 1).

$$
K_{c}=\frac{E T_{c}-E_{b}}{E T_{o}}
$$


173 where $K_{c}$ is crop coefficient (unitless); $E T_{c}$ is measured T. latifolia evapotranspiration

$174\left(\mathrm{~mm} \mathrm{~h}^{-1}\right) ; E T_{o}$ is reference evapotranspiration $\left(\mathrm{mm} \mathrm{h}^{-1}\right)$; and $E_{b}$ is baseline evaporation 175 measured $\left(\mathrm{mm} \mathrm{h}^{-1}\right)$.

176 Baseline evaporation is included in the calculation of $E T_{c}$ to account for incoming

177 latent heat from the inflow (Kadlec, 2006). $K_{c}$ and $E_{b}$ were determined for the small-

178 stand T. latifolia in lysimeter using a linear regression of $E T_{c}$ versus $E T_{o}$ (Eqn. 4).

179

$$
\begin{array}{ll}
E T_{c}=\left(E T_{o} \times K_{c}\right)+E_{b} & \text { Eqn. } 4
\end{array}
$$

180 The calculated lysimeter $K_{c}$ was compared with the large-stand wetland $K_{c}$ value (Abtew

181 and Obeysekera, 1995) to predict differences in water loss expected between pilot-scale

182 and full-scale CWTSs.

\subsection{Analytical Evapotranspiration Performance Model}

184 A first-order, one-dimensional, steady-state model for estimating the effects of 185 evapotranspiration on treatment performance of a CWTS was derived from a conceptual, 186 serial connection of continuously stirred tank reactors (CSTRs), also known as the tank-

187 in-series (TIS) model proposed by Levenspiel (1972). Treatment performance was

188 evaluated on the basis of CWTS removal extent (i.e. final outflow constituent

189 concentration) and removal efficiency (i.e. percentage of constituent removed from

190 inflow to outflow by the CWTS). The TIS model was selected because it can be used to

191 recreate the hydrodynamics of FWS wetlands when the number of CSTRs connected in

192 series $(\mathrm{N})$ is calibrated to tracer test breakthrough data (Kadlec and Wallace, 2009). Other

193 models utilizing conceptual plug-flow-reactors (PFRs) and plug-flow-reactors with

194 dispersion (PFD) have been suggested for CWTSs, but may not be ideal because they are 
195 not accurate within the mixing ranges for FWS CWTSs identified through tracer tests

196 (Kadlec and Wallace, 2009; Levenspiel, 1972). In addition, the TIS model can be

197 calculated as a series of mass balances using simple algebra.

198 The TIS model used to determine treatment performance consisted of 16 CSTRs

$199(\mathrm{~N}=16)$ of unit area connected in series. This $\mathrm{N}$ value was selected to model a CWTS

200 with four wetland cells and is based on the mean $\mathrm{N}$ value previously determined for

201 single FWS CWTS cells ( $=4.1$; Bavor et al., 1988; Kadlec, 1994; Kadlec and Wallace,

202 2009; Nolte and Associates, 1998; Wang and Jawitz, 2006). The model was derived from

203 the wetland mass balance and first-order removal kinetics (Eqn. 5).

204

$$
Q_{\text {in }} C_{\text {in }}-Q_{\text {out }} C_{\text {out }}=k C_{\text {out }}(A \times d)
$$

Eqn. 5

205 where $Q_{\text {in }}$ is volumetric inflow to the $\operatorname{CSTR}\left(\mathrm{m}^{3} \mathrm{~d}^{-1}\right) ; C_{i n}$ is constituent concentration of

$206 Q_{\text {in }}\left(\mathrm{g} \mathrm{m}^{-3}\right) ; Q_{\text {out }}$ is volumetric outflow of the CSTR $\left(\mathrm{m}^{3} \mathrm{~d}^{-1}\right) ; C_{\text {out }}$ is constituent

207 concentration of $Q_{\text {out }}\left(\mathrm{g} \mathrm{m}^{-3}\right) ; k$ is volumetric first-order removal coefficient $\left(\mathrm{d}^{-1}\right) ; A$ is

208 surface area of the CSTR $\left(\mathrm{m}^{2}\right)$; and $d$ is water depth of the CSTR (m).

209 Assuming a unit area for $A$, rearrangement of Eqn. 5 yields the equation:

210

$$
q_{\text {in }} C_{\text {in }}-q_{\text {out }} C_{\text {out }}=k C_{\text {out }} \times d
$$

Eqn. 6

211 where $q_{\text {in }}$ is inflow hydraulic loading $\left(\mathrm{m} \mathrm{d}^{-1}\right)$; and $q_{\text {out }}$ is outflow $\left(\mathrm{m} \mathrm{d}^{-1}\right)$.

212 Eqn. 6 rearranged for $C_{\text {out }}$ :

$$
C_{\text {out }}=\frac{q_{\text {in }} C_{\text {in }}}{q_{\text {out }}+(k \times d)}
$$

Eqn. 7

214 Because $q_{\text {out }}$ is the difference between $q_{\text {in }}$ and water loss due to plant evapotranspiration $215\left(E T_{c}\right)$, Eqn. 7 can be rewritten:

216

$$
C_{o u t}=\frac{q_{\text {in }} C_{\text {in }}}{q_{\text {in }}-E T_{c}+(k \times d)}
$$

Eqn. 8 
217 Or in discrete form to allow for calculation of $C_{\text {out }}$ for each of the 16 CSTRs (i from 1 to 218 16) in the TIS model:

219

$$
C_{(i)}=\frac{q_{(i-1)} C_{(i-1)}}{q_{(i-1)}-\frac{E T_{C}}{16}+(k \times d)}
$$

220 where $c_{(i)}$ is outflow constituent concentration of CSTR i $\left(\mathrm{g} \mathrm{m}^{3}\right) ; c_{(i-1)}$ is inflow

221 constituent concentration of CSTR $i\left(\mathrm{~g} \mathrm{~m}^{3}\right)$; and $q_{(i-1)}$ is inflow hydraulic loading $\left(\mathrm{m} \mathrm{d}^{-1}\right)$.

222 Eqn. 9 was used to model removal of a conservative constituent (e.g. boron,

\section{3 chloride, etc.) with a volumetric first-order removal coefficient of $0.2 \mathrm{~d}^{-1}$ and readily}

224 treatable constituent (e.g. nitrate, oil and grease, etc.) with a volumetric first-order

225 removal coefficient of $1.2 \mathrm{~d}^{-1}$ in both shallow (20-cm water depth) and deep (40-cm water 226 depth) FWS CWTSs operating with a 4-day nominal HRT under a range of $E T_{c}$ from 0 to $22730 \mathrm{~mm} \mathrm{~d}^{-1}$ (Table 2). $E T_{c}$ values selected for the model were based on pilot-scale $K_{c}$ 228 measured from the lysimeter and $K_{c}$ reported in previous studies for large-scale wetlands 229 containing T. latifolia and range from baseline evapotranspiration $\left(0 \mathrm{~mm} \mathrm{~d}^{-1}\right)$ to arid 230 desert reference evapotranspiration (12 $\mathrm{mm} \mathrm{d}^{-1}$; Einesr et al., 2010). Predictions from the 231 model were compared to demonstrate the potential effects of evapotranspiration on 232 removal efficiency of conservative and readily treatable constituents. In order to isolate 233 and examine the effects of changes to the water balance attributed to evapotranspiration 234 on treatment performance, removal rate coefficients used in the model were assumed to 235 be unaffected by changes in evapotranspiration. The effect of T. latifolia transpiration on vertical transport of dissolved 238 constituents in bench-scale CWTSs was measured by vertical tracer tests. These tests 
239 monitored hydrosoil electrical conductivity to detect differences in dissolved tracer

240 arrival between wetland cells containing mature plants and cells containing trimmed

241 plants. Eight 20-L buckets were prepared as bench-scale wetland cells by filling each

242 with approximately $20 \mathrm{~cm}$ of sandy sediment and approximately $8 \mathrm{~T}$. latifolia plants. The

243 buckets were watered and fertilized regularly and stored in a climate-controlled

244 greenhouse for 9 months to promote plant maturation. After the maturation period, $T$.

245 latifolia in 4 randomly selected cells were trimmed to a height of $30 \mathrm{~cm}$ above the

246 hydrosoil (corresponding to $5 \mathrm{~cm}$ above the waterline) immediately prior to each tracer

247 test to eliminate plant transpiration.

248 Surface water electrical conductivity data collected from each wetland cell were

249 used to formulate tracer solutions containing amounts of dissolved sodium chloride

250 needed to yield conductivity readings ten times greater than readings from the surface

251 water. This strength of tracer solution was selected to allow accurate resolution of tracer

252 arrival time.

253 Eight individual tracer tests (4 with untrimmed plants and 4 with trimmed plants)

254 were performed by placing a pair of HANNA Instruments® HI 98331 stainless steel

255 conductivity probes $5 \mathrm{~cm}$ below the hydrosoil surface of each cell. Prepared tracer

256 solution was then added to the cell by a FMI® QG400 pump at a rate of $12 \mathrm{~L} \mathrm{~h}^{-1}$. After 5

257 minutes, a second QG400 pumping at a rate of $12 \mathrm{~L} \mathrm{~h}^{-1}$ was connected to the system at a

258 height of $25 \mathrm{~cm}$ above the hydrosoil surface to remove excess tracer solution, maintaining

259 a constant head. This method allowed tracer solution to be added gently, attempting to

260 prevent vertical flow disturbances while allowing circulation of the tracer solution. 
Hydrosoil conductivity was measured every 5 minutes until increased electrical

262 conductivity readings were detected for a minimum of 3 consecutive measurements at

263 each probe. Mean arrival times for the four untrimmed and four trimmed cells were

264 compared using Welch's t-test to determine if plant transpiration significantly altered

265 flow through hydrosoil of the wetland cells $(\alpha=0.05)$. If a significant difference in tracer

266 arrival time between the untrimmed and trimmed wetland cells occurred, then it was

267 concluded that plant evapotranspiration plays a role in transporting constituents in FWS

268 CWTSs through the hydrosoil where specific redox conditions for treatment reactions

269 occur.

270

\section{$\underline{\text { 3. Results }}$}

\subsection{Pilot-scale Crop Coefficients for Typha latifolia}

272 A diurnal pattern of $E T_{c}$ was observed in the lysimeter, with lowest

273 evapotranspiration occurring in the early morning (approximately $0.2 \mathrm{~mm} \mathrm{~h}^{-1}$ ) and

274 greatest evapotranspiration occurring in the late afternoon (approximately $2 \mathrm{~mm} \mathrm{~h}^{-1}$;

275 Figure 3). A similar diurnal pattern was observed for the calculated $E T_{o} . E T_{o}$ was

276 consistently lower than $E T_{c}$ throughout the day and was slightly negative (approximately

$277-0.02 \mathrm{~mm} \mathrm{~h}^{-1}$ ) in the early morning when air temperature was below the dew point. Over

278 the duration of the experiment, measured mean air temperature was $27.4^{\circ} \mathrm{C}$, mean dew-

279 point was $21.4^{\circ} \mathrm{C}$, mean wind speed was $0.26 \mathrm{~m} \mathrm{~s}^{-1}$, and mean solar radiation was $260 \mathrm{~W}$

$280 \mathrm{~m}^{-2}$ (Table 3).

281 Linear regression of $E T_{c}$ versus $E T_{o}$ for the three periods during which

282 evapotranspiration was monitored in July and August (Figure 4) yielded a $K_{c}$ value of 2.5 
$283\left(\mathrm{R}^{2}=0.96\right)$ which is greater than the $K_{c}$ of $1.0\left(\mathrm{R}^{2}=0.86\right)$ reported for large wetlands 284 (Abtew and Obeysekera, 1995). Baseline evaporation $\left(E_{b}\right)$ identified from the intercept of 285 the linear regression was $0.3 \mathrm{~mm} \mathrm{~h}^{-1}$. A comparison of the measured volumetric outflow 286 from the lysimeter with theoretical volumetric outflow predicted from $E T_{o}, K_{c}, E_{b}$, and $S A$ 287 indicates a close match of observed and predicted evapotranspiration (Figure 5).

289 Predictions from the TIS model (Eqn. 9) indicate changes in treatment

290 performance associated with differing $E T_{c}$ from 0 to $30 \mathrm{~mm} \mathrm{~d}^{-1}$ (Figure 6). Treatment 291 performance of a conservative constituent $\left(k=0.2 \mathrm{~d}^{-1}\right)$ is predicted to be negatively 292 affected by increasing $E T_{c}$ at water depths of both $20 \mathrm{~cm}$ and $40 \mathrm{~cm}$ (Figures 6A, 6B). As $293 E T_{c}$ increased from 0 to $30 \mathrm{~mm} \mathrm{~d}^{-1}$, concentration removal efficiency of the conservative 294 constituent decreased from 54.2 to $25.4 \%$ at the $20-\mathrm{cm}$ water depth and from 54.2 to $29543.9 \%$ at the 40-cm water depth.

296 Treatment performance of a readily treatable constituent $\left(k=1.2 \mathrm{~d}^{-1}\right)$ is predicted 297 to be marginally enhanced by increasing $E T_{c}$ at both water depths (Figures 6C, 6D). As $298 E T_{c}$ increased from 0 to $30 \mathrm{~mm} \mathrm{~d}^{-1}$, concentration removal efficiency of the readily 299 treatable constituent increased from 98.5 to $99.0 \%$ at the 20 -cm water depth and from 30098.5 to $99.0 \%$ at the $40-\mathrm{cm}$ water depth. Tracer arrival times were consistently less in the wetland cells containing 303 untrimmed plants compared to the cells containing trimmed plants (Figure 7). Mean 304 tracer arrival time from all tracer tests was 104 minutes $(\sigma=25$ minutes $)$ in the 
untrimmed cells and 450 minutes ( $\sigma=57$ minutes) in the trimmed cells. Comparison of

306 mean arrival times in the untrimmed and trimmed cells indicates that tracer arrival times

307 were significantly different $\left(\mathrm{p}=1.2 \times 10^{-8}\right)$.

\section{$\underline{4 . \text { Discussion }}$}

309 Results from this study support the wetland oasis effect described by Idso and 310 Anderson (1988) where small, isolated wetlands have greater evapotranspiration than

311 large-stand wetlands. The calculated lysimeter crop coefficient $\left(K_{c}=2.5 \mathrm{R}^{2}=0.96\right.$;

312 Figure 4) for the 2- $\mathrm{m}^{2}$ lysimeter used in this study was more than two times greater than 313 the crop coefficient measured by Abtew and Obeysekera $\left(K_{c}=1.0 \mathrm{R}^{2}=0.86 ; 1995\right)$ for a 314 549-hectare T. latifolia wetland located in South Florida. Generally, evapotranspiration 315 from pilot-scale CWTSs is expected to be greater than full-scale CWTSs. The crop 316 coefficient measured in this study applies to mature plants and can be used to predict 317 evapotranspiration from small pilot-scale systems located in different climatic regions 318 where reference evapotranspiration is known or can be measured.

319 Lysimeter measurements indicate that volumetric outflow decreased to 320 approximately $1.2 \mathrm{~L} \mathrm{~h}^{-1}$ during peak evapotranspiration in the late afternoon (Figure 5), 321 corresponding to an $80 \%$ decrease in volume from inflow to outflow. Over the course of 322 each 24-hour period, the $6 \mathrm{~L} \mathrm{~h}^{-1}$ volumetric inflow decreased to a mean volumetric 323 outflow of $4.2 \mathrm{~L} \mathrm{~h}^{-1}$, indicating a daily volumetric loss of $30 \%$ of inflow. A $30 \%$ decrease 324 in water volume corresponds to a $43 \%$ increase in concentration of constituents as 325 predicted by the law of mass conservation. However, a 30\% loss of volumetric inflow is 
326 predicted to increase nominal HRT by approximately $20 \%$ based on the ratio of system 327 volume to volumetric inflow.

328 Differences in CWTS treatment performance attributed to increased

329 evapotranspiration are predicted by the model to depend on both water depth and

330 constituent removal rate coefficients. Because increased evapotranspiration is predicted

331 to have a deleterious effect on removal efficiency of conservative constituents,

332 evapotranspiration can lead to excessive salinity when CWTSs are used to treat brackish

333 or brine waters containing high concentrations of ions such as sodium and chloride. As

334 predicted by the model (Figure 6), water depth can be increased to mitigate the effects of

335 evapotranspiration; however, removal of targeted constituents can be altered by a change

336 in water depth due to changes in treatment conditions (Gillespie et al., 2000).

337 Because removal efficiency of readily treatable constituents is predicted to be

338 only marginally enhanced by increased evapotranspiration, lengthening of HRT caused

339 by evapotranspiration can overcome the increased concentration of constituents due to

340 water loss. As a result, properly designed CWTSs with sufficiently high removal rate

341 coefficients $\left(\sim 1.2 \mathrm{~d}^{-1}\right)$ for targeted constituents are predicted to be resilient to changes in

342 water loss due to evapotranspiration and can be modeled without considering changes in

343 the water balance caused by evapotranspiration.

344 Results from tracer tests verify the transpiration-driven vertical flow path

345 described by Martin et al. (2003). Therefore, it is likely that redox-driven reactions in

346 FWS CWTS hydrosoil (e.g. dissimilatory sulfate reduction and denitrification) can

347 contribute to removal of targeted constituents that require reducing conditions. Further 
research is required to determine the flux of water through hydrosoil of FWS wetlands by

349 plant transpiration; however, maximum flux will be bound by total measured plant

350 transpiration. Additionally, changes in flow through the hydrosoil under different

351 evapotranspiration can contribute to changes in performance and warrants further

352 investigation.

\section{$\underline{\text { 5. Conclusions }}$}

The crop coefficient for the $2-\mathrm{m}^{2}$ lysimeter was determined to be 2.5 times greater

$355\left(K_{c}=2.5, \mathrm{R}^{2}=0.96\right)$ than the crop coefficient previously reported for a large-stand $T$.

356 latifolia wetland $\left(K_{c}=1.0, \mathrm{R}^{2}=0.86\right)$. The difference in the crop coefficient measured for

357 the lysimeter used in this study and large-stand T. latifolia wetlands supports the oasis

358 effect described in previous studies. As evapotranspiration increases from 0 to $30 \mathrm{~mm} \mathrm{~d}^{-1}$,

359 the TIS model predicts that concentration removal efficiency for conservative

360 constituents is negatively affected (from 54.2 to $25.4 \%$ at 20 -cm water depth), while

361 concentration removal efficiency for readily treatable constituents is marginally enhanced

362 (from $98.5 \%$ to $99.5 \%$ at 20 -cm water depth). In addition, plant transpiration significantly

$363\left(\mathrm{p}=1.2 \times 10^{-8}\right)$ enhanced vertical transport of constituents through FWS CWTS

364 hydrosoil. Results from the lysimeter study and TIS model may be applied to predicting

365 differences in evapotranspiration and performance between pilot-scale and full-scale

366 CWTSs and among CWTSs located in different climatic regions. Results from the

367 vertical tracer tests demonstrate the importance of plant transpiration on vertical flow of

368 constituents in FWS CWTSs and verify that constituents can be transported vertically

369 through the hydrosoil where redox-driven treatment reactions occur. 
371 We gratefully acknowledge funding provided by Clemson University and the

372 United States Department of Energy (USDOE) through the National Energy Technology

373 Laboratory under Award Number DE-NT0005682. This article was prepared as an

374 account of work sponsored by an agency of the United States Government. Neither the

375 United States Government nor any agency thereof, nor any of their employees, makes

376 any warranty, express or implied, or assumes any legal liability or responsibility for the

377 accuracy, completeness, or usefulness of any information, apparatus, product, or process

378 disclosed, or represents that its use would not infringe privately owned rights. Reference

379 herein to any specific commercial product, process, or service by trade name, trademark,

380 manufacturer, or otherwise does not necessarily constitute or imply its endorsement,

381 recommendation, or favoring by the United States Government or any agency thereof.

382 The views and opinions of authors expressed herein do not necessarily state or reflect

383 those of the United States Government or any agency thereof. 
$\underline{\text { References }}$

Abtew W. and J. Obeysekera, 1995. Lysimeter Study of Cattails and Comparisons of Three Estimation Methods. Trans ASAE, 38(1):121-129.

Allen, R.G., J.H. Prueger, and R.W. Hill, 1992. Evapotranspiration from Isolated Stands of Hydrophytes: Cattail and Bulrush. Trans ASAE, 35(4): 1191-1198.

Allen, L.H. Jr., T.R. Sinclair, and J.M. Bennett, 1997. Evapotranspiration of Vegetation of Florida: Perpetuated Misconceptions Versus Mechanistic Processes. Soil Crop Sci Soc Fla Proc, 56: 1-10.

Allen, R.G., L.S. Pereira, D. Raes, and M. Smith, 1998. Crop Evapotranspiration Guidelines for Computing Crop Water Requirements. Irrigation and Drainage Paper 65, United Nations Food and Agriculture Organization: Rome, Italy.

Anderson, M.G. and S.B. Idso, 1987. Surface Geometry and Stomatal Conductance Effects on Evaporation from Aquatic Macrophytes. Water Resour Bull, 23(6): 1037-1042.

Bavor, H.J., D.J. Roser, S.A. McKersie, and P.F. Breen, 1988. Treatment of Secondary Effluent. Report to Sydney Water Board, Sydney, NSW, Australia.

Dorman, L., J.W. Castle, and J.H. Rodgers Jr., 2009. Performance of a Pilot-scale Constructed Wetland Treatment System for Treating Simulated Ash Basin Water. Chemosphere, 75: 939-947.

Einesr, M., A. Alazba, and M. Abu-Zreig, 2010. Spatio-Temporal Variability of Evapotranspiration over the Kingdom of Saudi Arabia. App Eng Agric, 26(5): 833-842.

Gillespie, W.B. Jr., W.B. Hawkins, J.H. Rodgers Jr., M.L. Cano, and P.B. Dorn, 2000. Transfers and Transformations of Zinc in Constructed Wetlands: Mitigation of a Refinery Effluent. Ecol Eng, (14) 279-292.

Horner, J.E., J.W. Castle, J.H. Rodgers Jr., C.L. Murray-Gulde, and J.E. Myers, 2012. Design and Performance of Pilot-scale Constructed Wetland Treatment Systems for Treating Oilfield Produced Water from Sub-Saharan Africa. Water Air Soil Poll, 223: 1945-1957.

Idso, S.B., 1981. Relative Rates of Evaporative Water Losses from Open and Vegetation Covered Water Bodies. Water Resour Bull, 17(1): 46-48. 
Idso, S.B. and M.G. Anderson, 1988. A Comparison of Two Recent Studies of Transpirational Water Loss from Emergent Aquatic Macrophytes. Aquat Bot, 31: 191-195.

Kadlec, R.H., 1994. Detention and Mixing in Free Water Wetlands. Ecol Eng, 3(4): 345380.

Kadlec, R.H., 1999. Chemical, Physical and Biological Cycles in Treatment Wetlands. Water Sci Technol, 40(3): 37-44.

Kadlec, R.H., 2006. Water Temperature and Evapotranspiration in Surface Flow Wetlands in Hot Arid Climate. Ecol Eng, 26: 328-340.

Kadlec, R. H. and S.D. Wallace. 2009. Treatment Wetlands (2nd Edition). Boca Raton: Taylor and Francis Group LLC. pp. 107-113.

Kanagy, L.E., B.M. Johnson, J.W. Castle, and J.H. Rodgers Jr., 2008. Design and Performance of a Pilot-scale Hybrid Constructed Wetland Treatment System for Natural Gas Storage Produced Water. Bioresource Technol, 99: 1877-1885.

Levenspiel, O. 1972. Chemical Reaction Engineering. First Edition, John Wiley and Sons: New York.

Martin, J.F. and K.R. Reddy, 1997. Interaction and Spatial Distribution of Wetland Nitrogen Processes. Ecol Model, 105: 1-21.

Martin, J.F., E. Hofherr, and M. Quigley, 2003. Effects of Typha latifolia Transpiration and Harvesting on Nitrate Concentrations in Surface Water of Wetland Microcosms. Wetlands, 23(4): 835-844.

Nolte and Associates, 1998. Sacramento Regional Wastewater Treatment Plant Demonstration Wetlands Project: Five year Summary Report 1994-1998, Report to Sacramento Regional County Sanitation District, Nolte and Associates.

Otis, C.H., 1914. The Transpiration of Emersed Water Plants: Its Measurements and Its Relationships. Bot Gaz, 58: 457-494.

Penman, H.L., 1963. Vegetation and Hydrology. Technical Communication No. 53, Commonwealth Bureau of Soils, Harpenden, England.

Shaw, R.H. (Editor), 1967. Ground Level Climatology. American Association for the Advancement of Science Publication No. 86, Washington D.C. 
Snyder R.L. and C.E. Boyd, 1987. Evapotranspiration of Eichhornia crassipes (Mart.) and Typha latifolia (L.). Aquat Bot, 27: 217-27.

Spacil, M.M., J.H. Rodgers Jr., J.W. Castle, and W.Y. Chao, 2011. Performance of a Pilot-Scale Constructed Wetland Treatment System for Selenium, Arsenic, and Low Molecular Weight Organics in Simulated Fresh Produced Water. Environ Geosci, 18: 145-156.

Towler, B.W., J.E. Cahoon, and O.R. Stein, 2004. Evapotranspiration Crop Coefficients for Cattail and Bulrush. J Hydrol Eng, 9: 235-239.

Wang, H. and J.W. Jawitz, 2006. Hydraulic Analysis of Cell-Network Treatment Wetlands. J Hydrol, 330(3-4): 721-734. 
Figure 1. Excavated T. latifolia with root mass showing root growth above the hydrosoil surface. Arrows indicate hypothesized flow path generated by plant transpiration.

Figure 2. Schematic diagram of the $2-\mathrm{m}^{2}$ lysimeter showing all four $0.5-\mathrm{m}^{2}$ containerized wetland troughs connected in series. Water was supplied to the first trough at a rate of $\left(6 \mathrm{~L} \mathrm{~h}^{-1}\right)$ and volumetric outflow was recorded by a RainWise ${ }^{\circledR}$ tipping bucket rain gauge located at the outflow of the last trough.

Figure 3 . Hourly plot of measured evapotranspiration $\left(E T_{c}\right)$ and calculated reference evapotranspiration $\left(E T_{o}\right)$. Evapotranspiration was lowest during the evening and greatest in the late afternoon.

Figure 4. Linear regression of $E T_{c}$ versus $E T_{o}$. The slope value of 2.5 yields the crop coefficient $\left(K_{c}\right)$ for pilot-scale CWTSs containing T. latifolia.

Figure 5. Comparison of measured volumetric outflow from the lysimeter and volumetric outflow predicted using $E T_{o}, K_{c}$, and $E_{b}$. Mean volumetric outflow from the lysimeter during this 4-day period was $4.2 \mathrm{~L} \mathrm{~h}^{-1}$.

Figure 6. TIS model results showing outflow concentrations of the 16 CSTRs during evapotranspiration from 0 to $30 \mathrm{~mm} \mathrm{~d}^{-1}$ for: (A) Conservative constituent $\left(0.2 \mathrm{~d}^{-1}\right)$ at a water depth of $20 \mathrm{~cm}$, (B) conservative constituent at a water depth of $40 \mathrm{~cm}$, (C) readily treatable constituent $\left(1.2 \mathrm{~d}^{-1}\right)$ at a water depth of $20 \mathrm{~cm}$, (D) readily treatable constituent at a water depth of $40 \mathrm{~cm}$. As evapotranspiration increased from 0 to $30 \mathrm{~mm} \mathrm{~d}^{-1}$, concentrations of the conservative constituent at outflow from the final CSTR (16) increased at water depths of both 20 and $40 \mathrm{~cm}$, indicating a decrease in treatment performance (A and B). Treatment performance 
of the readily treatable constituent was marginally enhanced as evapotranspiration increased from 0 to $30 \mathrm{~mm}$ d-1 for both water depths as shown by the difference in outflow concentrations of the final CSTR (C and D).

507 Figure 7. Measured tracer arrival times at each of the two conductivity probes (P1 and 508 P2) for both untrimmed and trimmed wetland cells. The arrival times were consistently lower in the untrimmed cells than the trimmed cells indicating transpiration-driven vertical transport of tracer through hydrosoil. 
Figures

ন

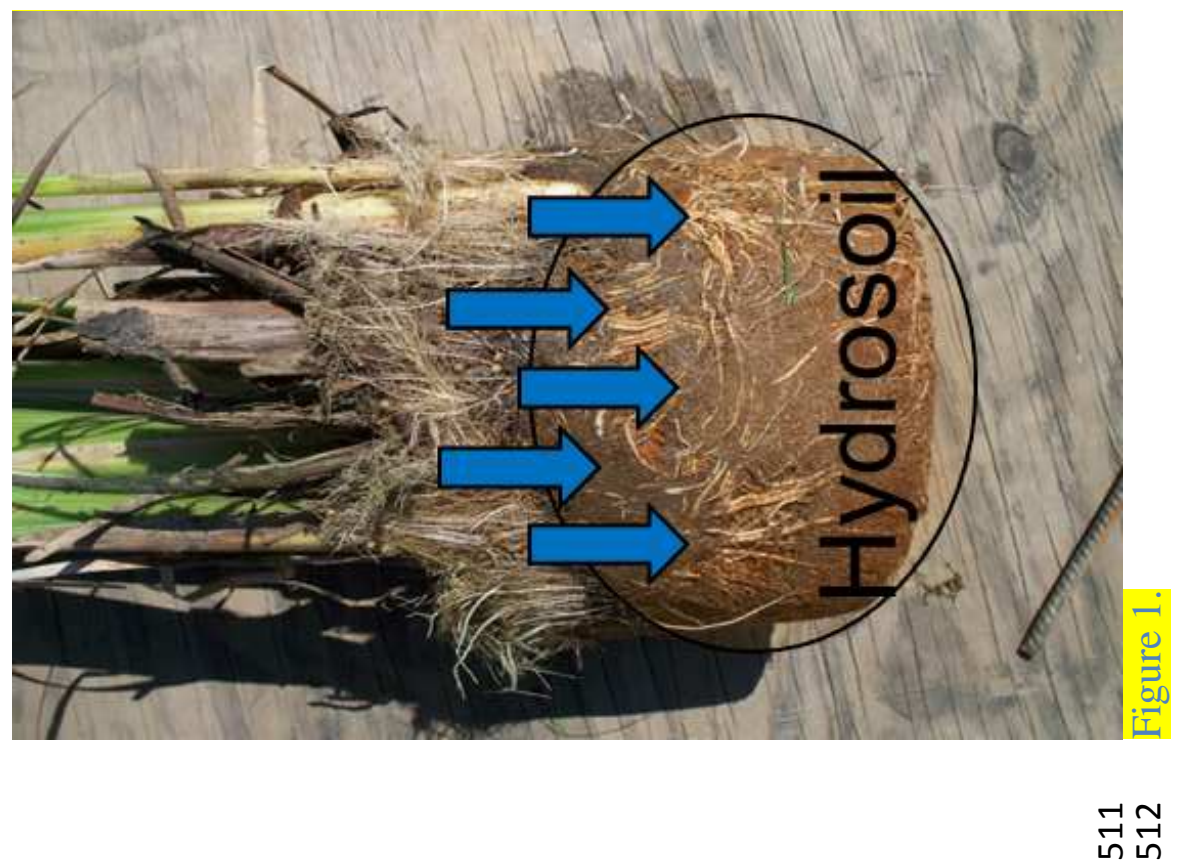




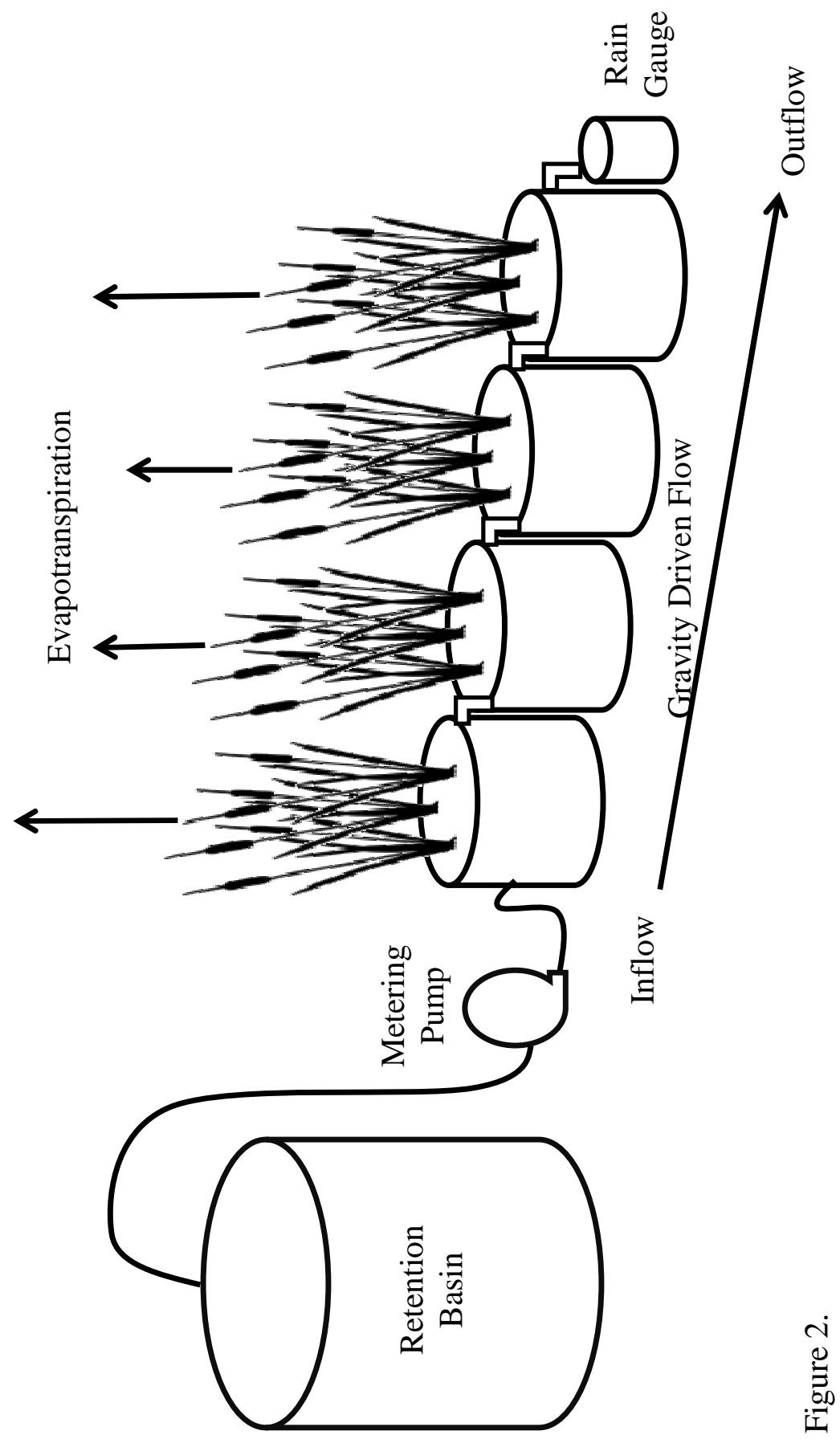

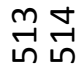




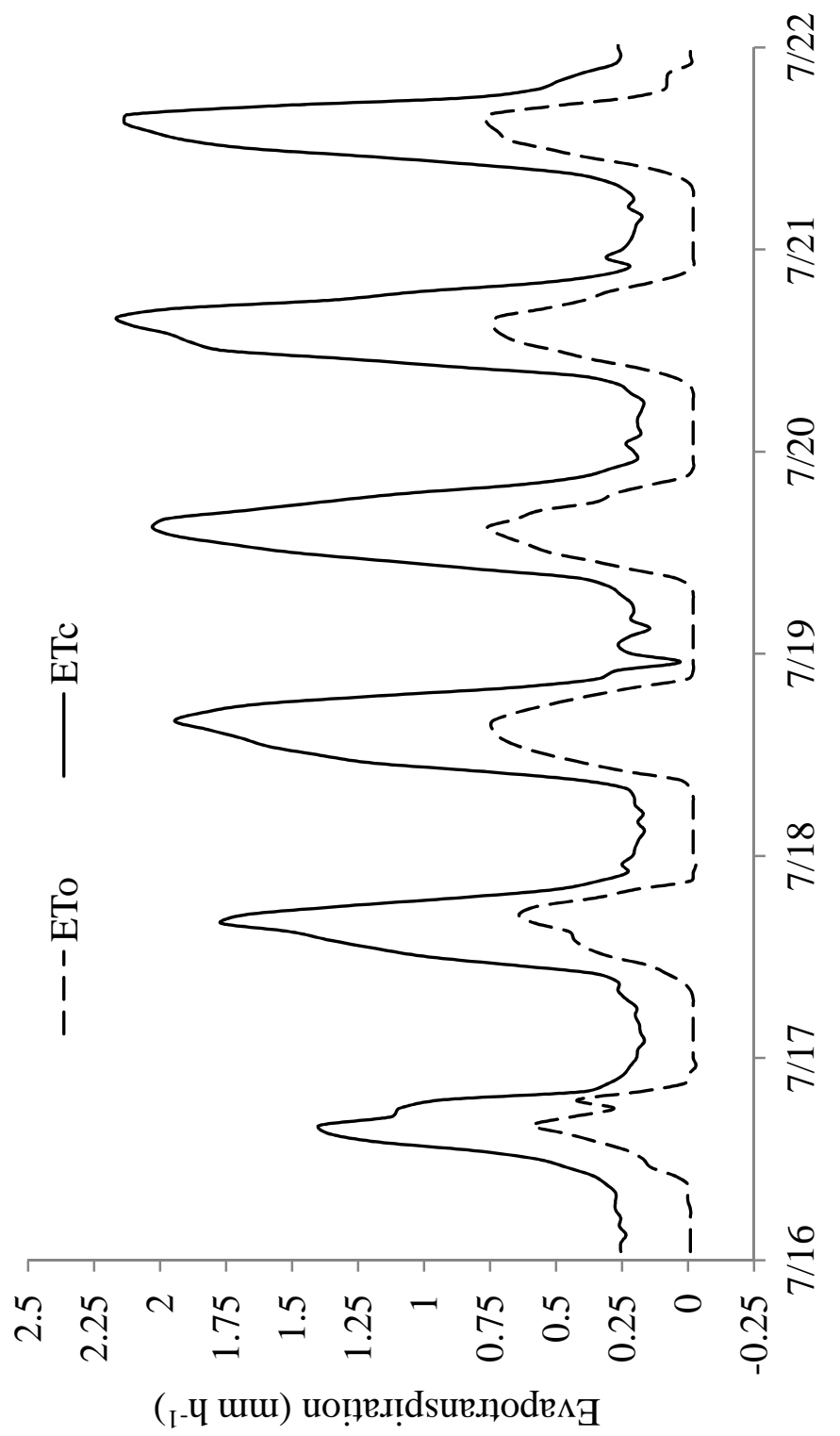




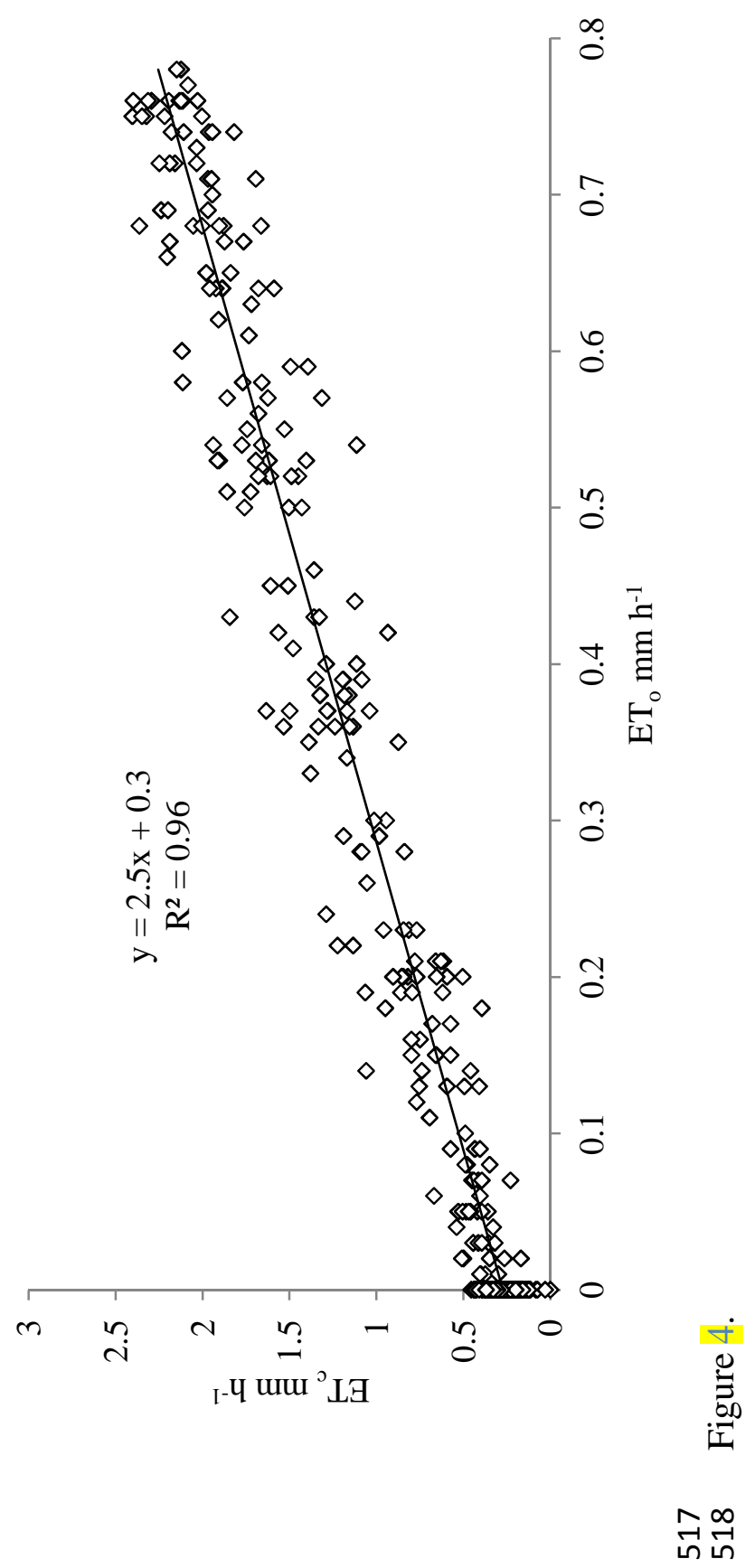




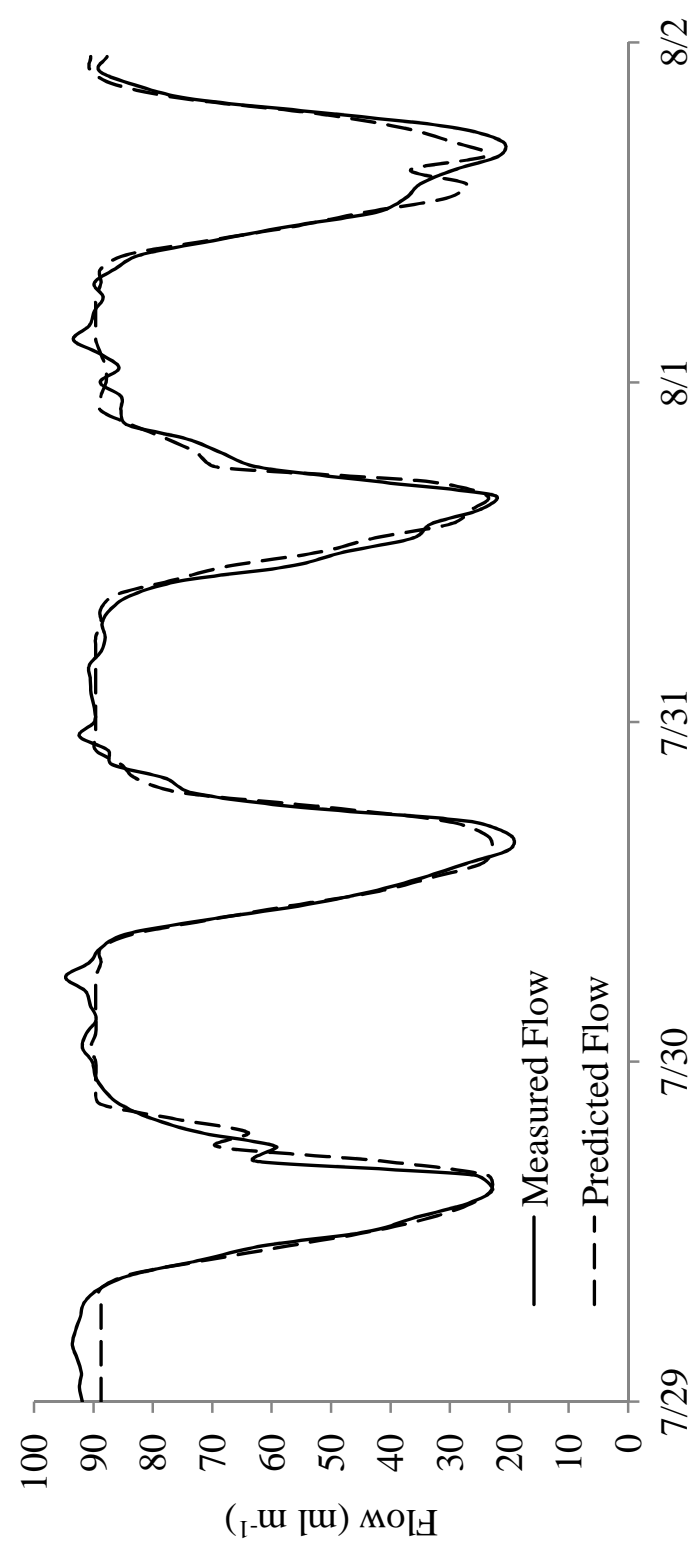

$\frac{1}{\infty}$

$\infty$

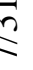

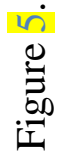

ㅇํำ 


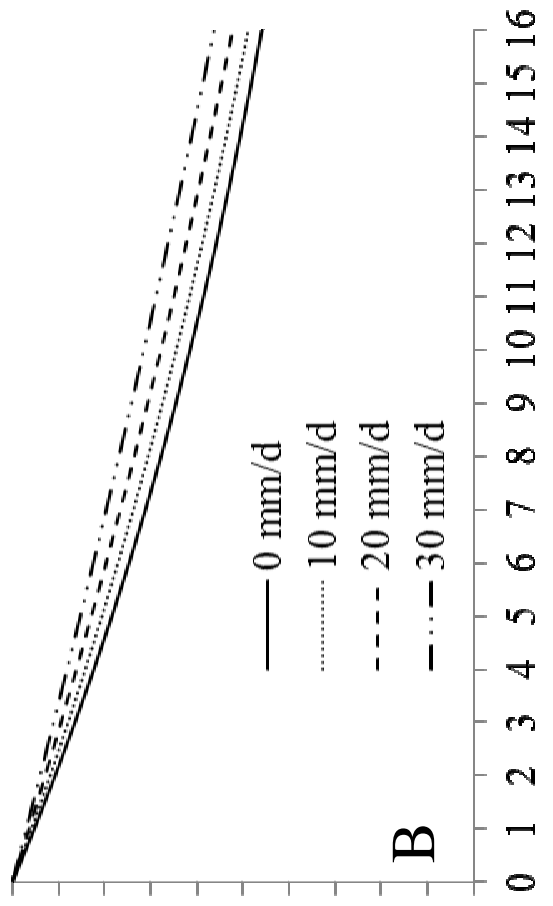

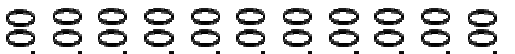
영요용용용ㅇㅇ

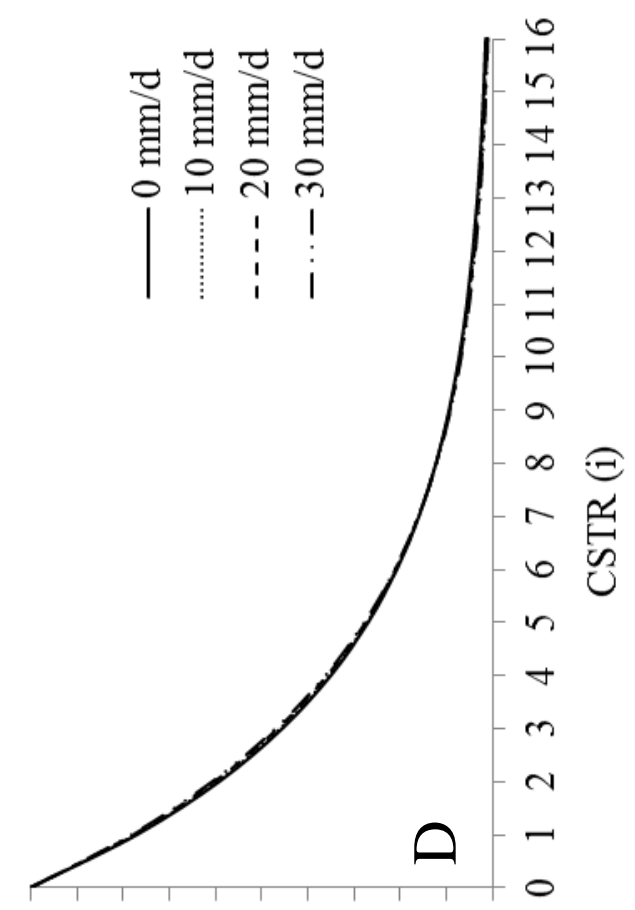

๑ㅇㅇㅇㅇㅇㅇ ๑

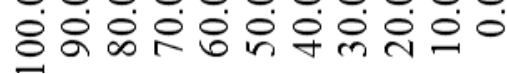

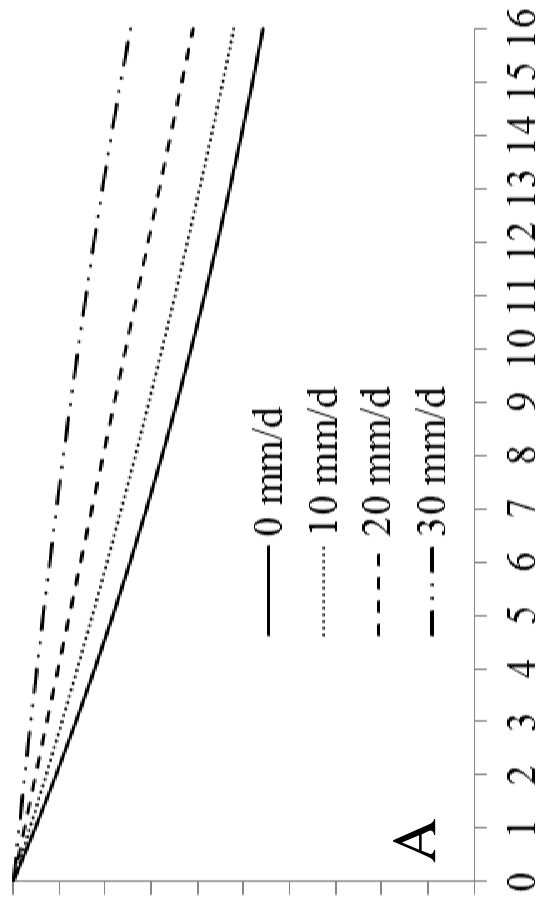

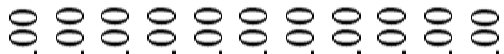

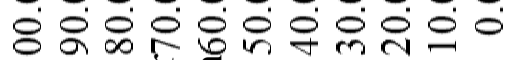

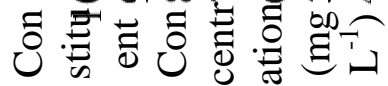

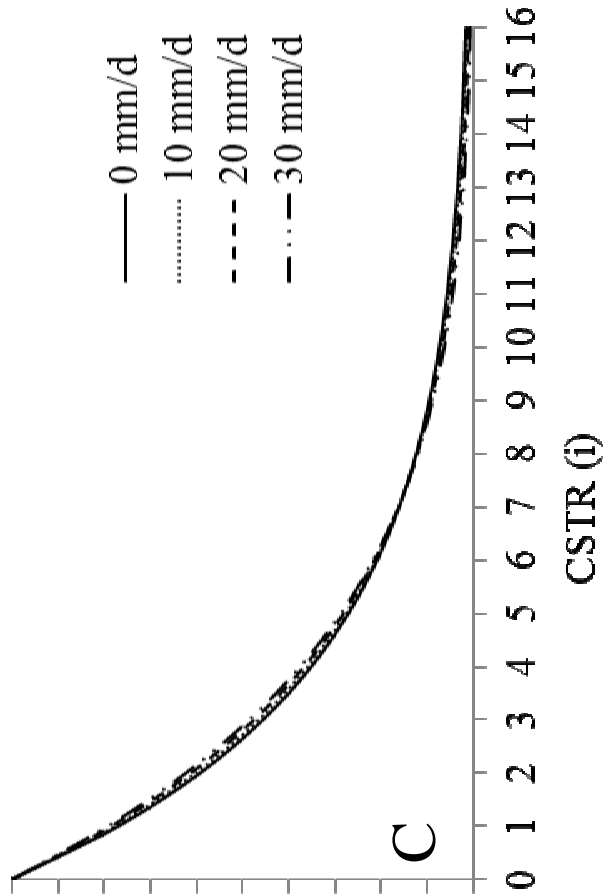

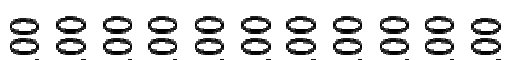

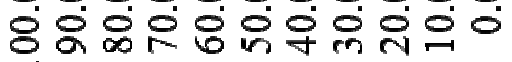

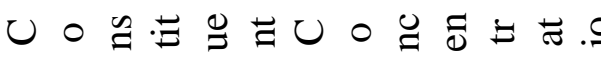




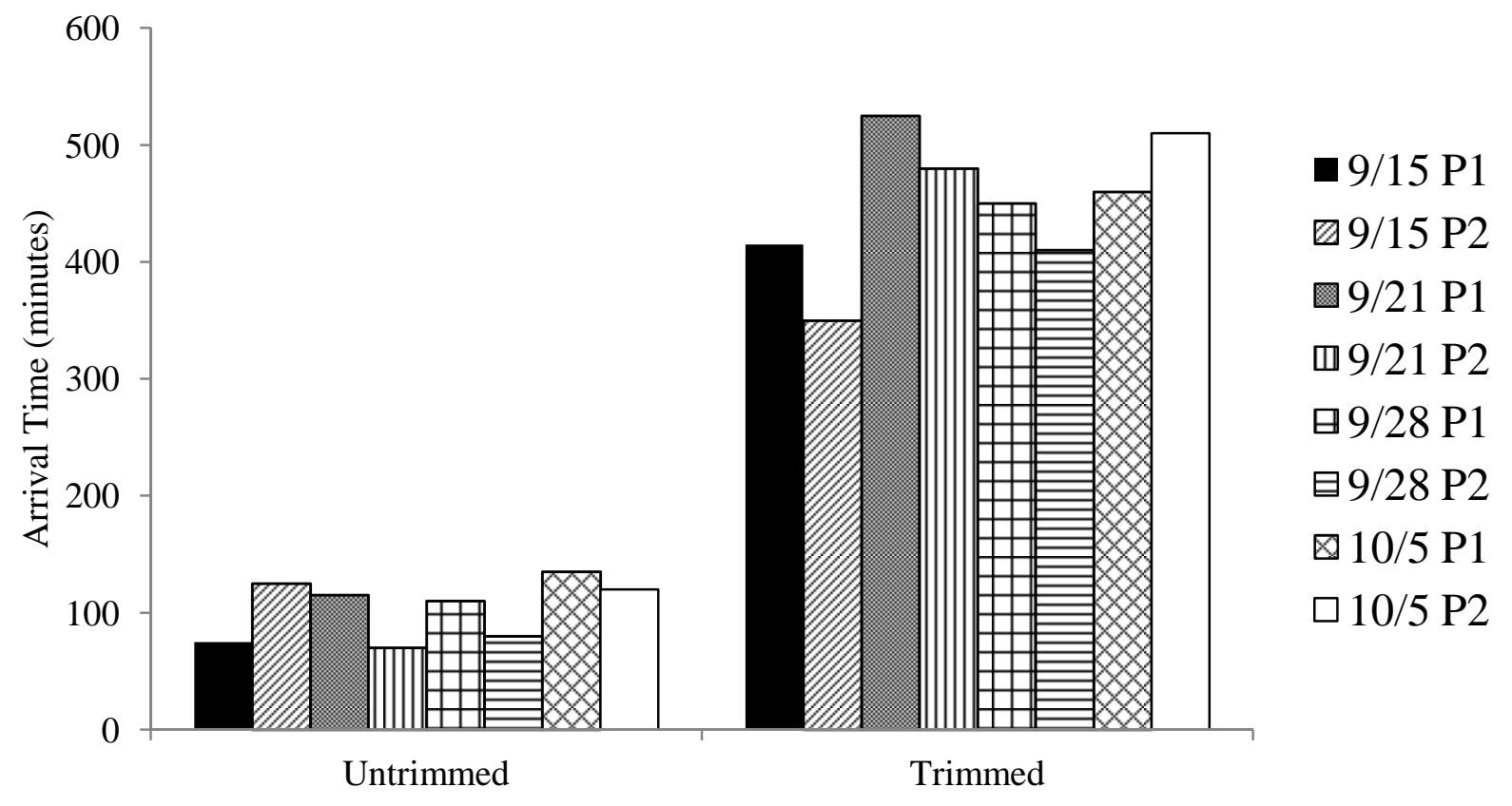

523

524

Figure 7. 
Table 1. Calculations for reference evapotranspiration equation (Eqn. 2)

Parameter
Symbol Units Formula vapor pressure curve

$$
\Delta \quad \mathrm{kPa}^{\circ} \mathrm{C}^{-1}
$$$$
\frac{4098\left[0.6108 \exp \left(\frac{17.27 \times T_{\text {mean }}}{T_{\text {mean }}+237.3}\right)\right]}{\left(T_{\text {mean }}+237.3\right)^{2}}
$$

Psychrometric constant

$\gamma \quad \mathrm{kPa}^{\circ} \mathrm{C}^{-1}$
$\left(6.65 \times 10^{-2}\right) \times P$

Saturation vapor pressure

$\mathrm{e}_{\mathrm{s}} \mathrm{kPa}$

$$
\frac{0.6108 \exp \left(\frac{17.27 \times T_{\max }}{T_{\max }+237.3}\right)-0.6108 \exp \left(\frac{17.27 \times T_{\min }}{T_{\min }+237.3}\right)}{2}
$$

Actual vapor pressure

$\mathrm{e}_{\mathrm{a}} \quad \mathrm{kPa}$

$$
0.6108 \exp \left(\frac{17.27 \times T_{\text {dew }}}{T_{\text {dew }}+237.3}\right)
$$


Table 2. Input parameters for scenarios modeled using a TIS receiving a hydraulic loading to maintain a nominal hydraulic retention time of 4 days and a constituent 528 concentration loading of $100 \mathrm{~g} \mathrm{~m}^{-3}$.

529

\begin{tabular}{ccccc}
\hline Scenario & $\begin{array}{c}\text { Evapotranspiration } \\
\left(\mathrm{mm} \mathrm{d}^{-1}\right)\end{array}$ & $\begin{array}{c}\text { Water Depth } \\
(\mathrm{m})\end{array}$ & \multicolumn{2}{c}{$\begin{array}{r}\text { Removal Rate Coefficieisp } \\
\left(1 \mathrm{~d}^{-1}\right)\end{array}$} \\
\hline 1 & 0 & 0.2 & 0.2 & 531 \\
2 & 10 & 0.2 & 0.2 & 533 \\
3 & 20 & 0.2 & 0.2 & 534 \\
4 & 30 & 0.2 & 0.2 & 535 \\
5 & 0 & 0.2 & 1.2 & 536 \\
6 & 10 & 0.2 & 1.2 & 537 \\
7 & 20 & 0.2 & 1.2 & 539 \\
8 & 30 & 0.2 & 1.2 & \\
9 & 0 & 0.4 & 0.2 & 540 \\
10 & 10 & 0.4 & 0.2 & 541 \\
11 & 20 & 0.4 & 0.2 & \\
12 & 30 & 0.4 & 0.2 & 542 \\
13 & 0 & 0.4 & 1.2 & \\
14 & 10 & 0.4 & 1.2 & 543 \\
15 & 20 & 0.4 & 1.2 & \\
16 & 30 & 0.4 & 1.2 & 544 \\
\hline
\end{tabular}

545 
Table 3. Measured meteorological conditions during experiment period (July and August of 2011).

\begin{tabular}{lccc}
\hline Parameter & Mean & Standard Deviation & Range \\
\hline Temperature $\left({ }^{\circ} \mathrm{C}\right)$ & 27.4 & 4.6 & $16.1-38.4$ \\
Dew-point $\left({ }^{\circ} \mathrm{C}\right)$ & 21.4 & 2.6 & $11.7-26.6$ \\
Windspeed $\left(\mathrm{m} \mathrm{s}^{-1}\right)$ & 0.26 & 0.41 & $0.00-2.24$ \\
Solar Radiation $\left(\mathrm{w} \mathrm{m}^{-2}\right)$ & 260 & 331 & $0-1020$ \\
\hline
\end{tabular}

546 


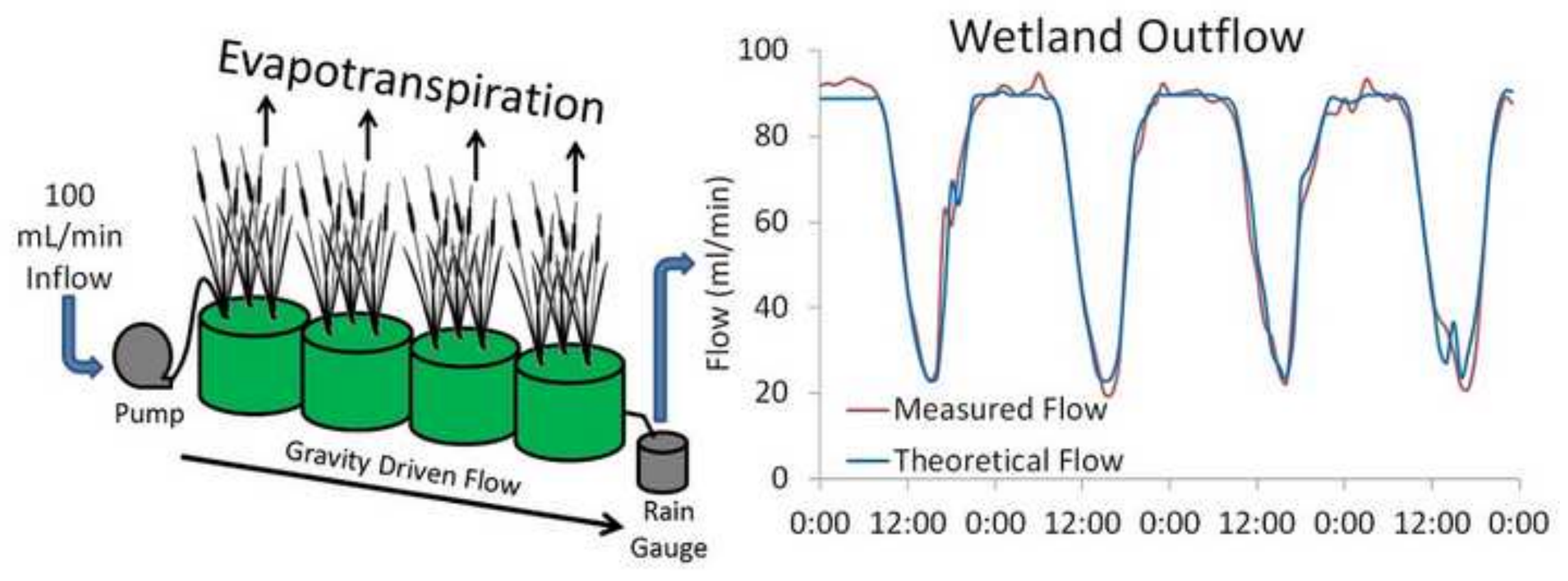

